\title{
Mediterranean winter rainfall in phase with African monsoon during past 1.36 million years
}

Bernd Wagner $^{1 * \dagger}$, Hendrik Vogel ${ }^{2} \dagger$, Alexander Francke ${ }^{1,3}$, Tobias Friedrich ${ }^{4}$, Timme Donders $^{5}$, Jack H. Lacey ${ }^{6}$, Melanie J. Leng ${ }^{6,7}$, Eleonora Regattieri ${ }^{8,9}$, Laura Sadori ${ }^{10}$, Thomas Wilke ${ }^{11}$, Giovanni Zanchetta ${ }^{8}$, Christian Albrecht ${ }^{11}$, Adele Bertini ${ }^{12}$, Nathalie CombourieuNebout $^{13}$, Aleksandra Cvetkoska ${ }^{5,11}$, Biagio Giaccio ${ }^{14}$, Andon Grazhdani ${ }^{15}$, Torsten Hauffe ${ }^{11}$, Jens Holtvoeth ${ }^{16}$, Sebastien Joannin ${ }^{17}$, Elena Jovanovska ${ }^{11}$, Janna Just ${ }^{1,18}$, Katerina Kouli ${ }^{19}$, Ilias Kousis ${ }^{20}$, Andreas Koutsodendris ${ }^{20}$, Sebastian Krastel ${ }^{21}$, Niklas Leicher ${ }^{1}$, Zlatko Levkov $^{22}$, Katja Lindhorst ${ }^{21}$, Alessia Masi ${ }^{10}$, Martin Melles ${ }^{1}$, Anna M. Mercuri ${ }^{23}$, Sebastien Nomade $^{24}$, Norbert Nowaczyk ${ }^{25}$, Konstantinos Panagiotopoulos ${ }^{1}$, Odile Peyron ${ }^{17}$, Jane M. $\operatorname{Reed}^{26}$, Leonardo Sagnotti ${ }^{27}$, Gaia Sinopoli ${ }^{10}$, Björn Stelbrink ${ }^{11}$, Roberto Sulpizio ${ }^{28,29}$, Axel Timmermann ${ }^{30,31}$, Slavica Tofilovska ${ }^{22}$, Paola Torri ${ }^{32}$, Friederike Wagner-Cremer ${ }^{5}$, Thomas Wonik $^{33}$, Xiaosen Zhang ${ }^{34}$

${ }^{1}$ Institute of Geology and Mineralogy, University of Cologne, Cologne, Germany.

${ }^{2}$ Institute of Geological Sciences \& Oeschger Centre for Climate Change Research, University of Bern, Bern, Switzerland.

${ }^{3}$ School of Earth, Atmospheric, and Life Science, University of Wollongong, Wollongong, Australia.

${ }^{4}$ International Pacific Research Center, University of Hawaii at Manoa, Honolulu, Hawaii, USA.

${ }^{5}$ Palaeoecology, Department of Physical Geography, Utrecht University, Utrecht, The Netherlands.

${ }^{6}$ National Environmental Isotope Facility, British Geological Survey, Nottingham, UK.

${ }^{7}$ Centre for Environmental Geochemistry, School of Biosciences, University of Nottingham, UK.

${ }^{8}$ Dipartimento di Scienze della Terra, University of Pisa, Pisa, Italy.

${ }^{9}$ Institute of Earth Sciences and Earth Resources-Italian National Research Council (IGGCNR), Pisa, Italy.

${ }^{10}$ Dipartimento di Biologia Ambientale, Università di Roma "La Sapienza", Rome, Italy.

${ }^{11}$ Department of Animal Ecology \& Systematics, Justus Liebig University Giessen, Giessen, Germany.

${ }^{12}$ Dipartimento di Scienze della Terra, Università di Firenze, Firenze, Italy.

${ }^{13}$ CNRS UMR 7194, Muséum National d'Histoire Naturelle, Institut de Paléontologie Humaine, Paris, France.

${ }^{14}$ Istituto di Geologia Ambientale e Geoingegneria - CNR, Rome, Italy.

${ }^{15}$ Faculty of Geology and Mineralogy, University of Tirana, Albania.

${ }^{16}$ School of Chemistry, University of Bristol, Bristol, UK.

${ }^{17}$ CNRS UMR 5554, Institut des Sciences de l'Evolution de Montpellier, Université de Montpellier, Montpellier, France.

${ }^{18}$ Fachbereich Geowissenschaften, Universität Bremen, Bremen, Germany. 
$41{ }^{19}$ Faculty of Geology and Geoenvironment, National and Kapodistrian University of Athens, 42 Athens, Greece.

$43{ }^{20}$ Paleoenvironmental Dynamics Group, Institute of Earth Sciences, Heidelberg University, 44 Heidelberg, Germany.

$45 \quad{ }^{21}$ Institute of Geosciences, Christian-Albrechts-Universität zu Kiel, Kiel, Germany.

$46 \quad{ }^{22}$ University Ss Cyril and Methodius, Institute of Biology, Skopje, FYROM.

$47 \quad{ }^{23}$ Dipartimento di Scienze della Vita, Laboratorio di Palinologia e Paleobotanica, Università 48 di Modena e Reggio Emilia, Modena, Italy.

$49{ }^{24}$ Laboratoire des Sciences du Climat et de l'Environnement, UMR 8212, CEA/CNRS/UVSQ

50 et Université Paris-Saclay, Gif-Sur-Yvette, France.

$51{ }^{25}$ Helmholtz Centre Potsdam, GFZ German Research Centre for Geosciences, Potsdam,

52 Germany.

$53{ }^{26}$ The Department of Geography, Geology and Environment, University of Hull, Hull, UK.

$54 \quad{ }^{27}$ Istituto Nazionale di Geofisica e Vulcanologia, Rome, Italy.

$55{ }^{28}$ Dipartimento di Scienze della Terra e Geoambientali, University of Bari, Bari, Italy.

$56{ }^{29}$ IDPA-CNR, Milan, Italy.

$57{ }^{30}$ Center for Climate Physics, Institute for Basic Science, Busan, South Korea

$58 \quad{ }^{31}$ Pusan National University, Busan, South Korea

$59{ }^{32}$ Dipartimento di Scienze della Vita, Laboratorio di Palinologia e Paleobotanica, Università 60 di Modena e Reggio Emilia, Modena, Italy.

$61{ }^{33}$ Leibniz Institute for Applied Geophysics (LIAG), Hannover, Germany.

$62{ }^{34}$ Institute of Loess Plateau, Shanxi University, Taiyuan, China.

63

$64 *$ Correspondence to: wagnerb@uni-koeln.de.

$65 \uparrow$ these authors contributed equally to this work. 
Precipitation is a key factor for socioeconomic development in densely populated and summer

69 dry regions such as the Mediterranean realm. Seasonal and regional changes are critical, but difficult to project accurately. While current climate model simulations indicate a progressive summer drying over the next century, precipitation changes during winter months are less well constrained ${ }^{1}$. Only a few continental proxy records capable of capturing hydroclimate change cover multiple Northern Hemisphere summer insolation maxima ${ }^{2,3}$ with different underlying orbital geometries, necessary to validate climate model data on Quaternary time scales. Here we use a 1.36 million year proxy time series from Lake Ohrid, coupled to a long transient climate model hind cast, to show that high winter precipitation anomalies occur during phases with strong seasonal contrast in insolation and high African summer monsoon activity. While this is counter-intuitive at first sight, our data suggest that increased seasurface temperatures amplify local cyclogenesis while also refuelling North Atlantic low pressure systems entering the Mediterranean during phases characterized by low continental ice volume and high atmospheric $\mathrm{CO}_{2}$ concentrations. Comparison with modern reanalysis data shows that current drivers of rainfall amount in the Mediterranean share some similarities to those driving the reconstructed precipitation increases. Our extended record covers multiple insolation maxima and therefore is an important benchmark for testing climate-model performance.

Mediterranean climates are characterized by strong seasonal contrasts between dry and warm summers, and wet and mild winters. The amount and temporal extent of precipitation during the winter half-year (October through March) determines the prevailing type of vegetation

91 and water availability for agrarian land-use in the Mediterranean borderlands. In recent decades, reduction of winter precipitation has become a regular phenomenon in this region, 
with anthropogenic greenhouse gas $(\mathrm{GHG})$ and aerosol forcing identified as potential contributors ${ }^{4}$. Current climate model simulations, using the Representative Concentration Pathway (RCP) 4.5 and 8.5 scenarios, predict a progressive summer drying over the next century ${ }^{1}$. Precipitation changes during the Northern Hemisphere $(\mathrm{NH})$ winter months are less well constrained, with different simulation runs showing trends both towards wetter and drier conditions. The uncertainty in winter precipitation projections limits the extent to which current modelling approaches are useful for decision makers ${ }^{5,6}$.

Long-term, empirical baseline data are helpful to constrain uncertainties in climate modelling proxy records. Proxy records and modelling experiments suggest that enhanced precipitation in the Mediterranean region is in phase with the northward shift of the intertropical convergence zone (ITCZ) and increase in African monsoon strength during precession minima causingNorthern Hemisphere summer insolation (NHSI) maxima and winter insolation (NHWI) minima ${ }^{2,7,8,9}$. However, most continental records that are capable of capturing hydroclimate change do not cover multiple NHSI maxima with different underlying orbital geometries. In fact, the majority of records are limited to the Holocene ${ }^{10,11}$, yet the Early Holocene NHSI maximum was relatively weak compared to most other Quaternary interglacials, due to lower eccentricity. Terrestrial proxy time series covering multiple NHSI maxima from the Mediterranean region are scarce ${ }^{2,3}$. Sediment records from the Mediterranean Sea provide continuity throughout the Plio-Pleistocene and capture cessations of deep-water ventilation associated with the formation of prominent, organic-rich sapropel layers $^{12,13}$. While multiple factors contribute to sapropel formation, increased freshwater input, particularly from the African continent during NHSI-forced monsoon maxima, is considered the most important ${ }^{14,15}$. Hence, the Mediterranean sapropel record is thought to be an excellent indicator of the relative timing of increased African monsoon strength rather than a direct indicator of precipitation in, and runoff from, the entirety of the Mediterranean realm. Reconstructed precipitation increases in the northern Mediterranean borderlands during 
sapropel formation have been interpreted to be a product both of intensified summer and winter precipitation ${ }^{15,16}$. Modelling experiments explain increased winter precipitation by

121 stronger wintertime storm tracks ${ }^{2}$ or air-sea temperature difference, and locally induced convective precipitation that dominate freshwater budget changes on obliquity time scales ${ }^{17}$.

123 Alternatively, conceptual models based on proxy time series have suggested increases in the

124 frequency and intensity of low-pressure systems evolving in the Mediterranean region, mostly

125 during fall and early winter ${ }^{7,8,16}$. Hence, a well-dated proxy record covering multiple glacial-

126 interglacial cycles and being sensitive to changes in Mediterranean hydroclimate is key to

127 addressing long-standing questions regarding the underlying mechanisms, timing, and

128 amplitude of precipitation variability under different climate boundary conditions (GHG

129 concentration, orbital geometries, continental ice sheet volume and extent).

Here, we assess precipitation variability in a continuous, independently dated 1.36

131 Myr sedimentary record from Lake Ohrid (Fig. 1, Extended Data Fig. 1). Climate variations at 132 this site represent broader climate variability across the northern Mediterranean borderlands ${ }^{18}$.

133 We compare our sedimentary proxy time series with transient climate simulation data and

134 prominent monsoon records, to provide a mechanistic understanding of precipitation

135 variability and seasonality, as well as phase relationships to orbital forcing. Lake Ohrid is of tectonic origin and $293 \mathrm{~m}$ deep. The lake is hydrologically open and 137 primarily fed by an extensive karst aquifer system, which supplies ions (mainly $\mathrm{Ca}^{2+}$ and $\left.138 \mathrm{HCO}_{3}{ }^{-}\right)$to the lake and filters particulate matter ${ }^{19}$. Scientific drilling in 2013 resulted in a 584139 m-long composite sediment succession from the lake centre, comprised of fine-grained hemi140 pelagic muds in the upper $447 \mathrm{~m}^{18,20}$. Sedimentation is thought to have been uninterrupted, 141 with no evidence of unconformities or erosion surfaces. Independent age control from 16 142 interspersed tephra layers in combination with magnetostratigraphy (Fig. 1, Extended Data 143 Fig. 2, Extended Data Table 1, Extended Data Table 2) provides a robust chronological 
144 framework. This framework allows us to match changes in orbital parameters with our proxy 145 data to refine the age-depth relationships. The data demonstrate that the Lake Ohrid record 146 spans the last 1.36 Myr (Fig. 1). Indicators for detrital input (quartz, potassium), catchment vegetation (arboreal pollen excluding pine (AP-P), deciduous oaks), and hydrological variability (total inorganic carbon (TIC), $\mathrm{Ca} / \mathrm{K}, \delta^{18} \mathrm{O}_{\text {calcite, }} \delta^{13} \mathrm{C}_{\text {calcite }}$ ) show clear orbital-scale cyclicity, also characterized by a precessional ( 21 ka) component (Fig. 2; Extended Data Figs 3, 4, and 5). During periods of 151 global ice volume minima and NHSI maxima, we observe prominent peaks in the hydrological and vegetation proxy data (Fig. 2). We interpret these peaks in TIC (mainly from endogenic calcite) and $\mathrm{Ca} / \mathrm{K}$ (a proxy for the concentration of calcite) to result from enhanced

154 activity of, and ion supply from, the karst aquifers combined with higher aquatic productivity 155 due to warmer conditions ${ }^{19}$. Pollen show a simultaneous increase in vegetation cover, 156 particularly deciduous oaks, during early phases of interglacials. Deciduous oaks benefit from 157 a limited length of the summer dry season ${ }^{21}$. Lower $\delta^{13}$ Calcite values during these periods 158 suggest greater soil development, while lower $\delta^{18} \mathrm{O}_{\text {calcite }}$ (Extended Data Fig. 3) indicate more 159 positive precipitation/evaporation $(\mathrm{P} / \mathrm{E})$ balance $^{18}$. Thus, aquatic and terrestrial datasets 160 suggest higher temperatures along with maxima in annual precipitation amount and potential 161 shorter summer aridity during interglacials (Extended Data Fig. 4). To provide a better understanding of the observed precipitation variability from the

163 Lake Ohrid record in a regional context, we analysed climate data time series derived from a 164 transient $784 \mathrm{kyr}$ simulation using the earth system model LOVECLIM ${ }^{22,23}$ (Extended Data 165 Fig. 6) as well as NOAA reanalysis precipitation data of the Lake Ohrid region for the time 166 period 1979-2017. Temperature time series of the $5^{\circ} \times 5^{\circ}$ Lake Ohrid grid cell simulated by 167 the LOVECLIM earth system model closely resemble records of first-order global ice volume 168 (Extended Data Fig. 3), such as the LR04 benthic oxygen isotope $\operatorname{stack}^{24}(\mathrm{r}=0.8737$ or 
$169 r^{2}=0.76$ based on 1000 -year averages of both data sets). The close match to changes in the

170 amount of detrital siliciclastics and tree pollen (AP-P) confirms the sensitivity of the Lake

171 Ohrid record to global-scale climate fluctuations (Fig. 2; Extended Data Figs 3 and 4). The

172 highest amplitudes in precipitation time series occur during phases of reduced ice volume,

173 with prominent peaks during NHSI maxima. The significant positive relationship between

174 simulated precipitation and our precipitation proxy time series $\left(\mathrm{r}^{2}=0.38\right)$ and the persistence of

175 the relationship with the orbital parameters (Extended Data Fig. 4) suggest that the local

176 response recorded at Lake Ohrid also captures changes in regional hydroclimate back to 1.36

177 Ma (Fig. 2).

Seen both in paleo records and in climate model simulations, the intensification of $\mathrm{NH}$ monsoon systems during precession minima and NHSI maxima is a prominent example of 180 orbitally-forced changes in precipitation variability ${ }^{14,15,25}$. Iconic records of monsoon strength, 181 such as the Chinese speleothem ${ }^{26}$, eastern Mediterranean sapropel ${ }^{12,13,26}$ and planktonic 182 foraminifera oxygen isotope records ${ }^{14,15,27}$, show a positive phase relationship with Lake

183 Ohrid hydrological proxy time series (Fig. 2). Strengthening of NH monsoons results from a 184 northward displacement of atmospheric circulation systems, including the position of the 185 Hadley cells and the ITCZ during NH summer. The shift of the Hadley cell amplifies 186 subsidence over, and persistence of, high-pressure systems in the Mediterranean region, 187 leading to warmer and drier summers ${ }^{17}$, and higher sea-surface temperatures (SST) ${ }^{16,28}$. 188 Reduced NHWI has highest impact on tropical and subtropical latitudes ${ }^{2}$ and leads to low 189 latitude cooling and a southward shift of the ITCZ and the NH Hadley and Ferrel cells. 190 Furthermore, this cooling results in a reduced meridional temperature gradient leading to a 191 weakening of the westerlies based on the thermal wind relationship. The observed 192 relationship between the Lake Ohrid precipitation record (Fig. 2, Extended Data Figs 3 and 4) 193 and the monsoon archives suggests increased precipitation during the winter half-year for this 194 region when NHWI is low. 
The Lake Ohrid record, in combination with the transient simulation time series and the NOAA reanalysis data, may provide fundamental insights into the mechanisms invoked by orbital forcing on Mediterranean precipitation. The monthly NOAA reanalysis data of the last 39 years show high precipitation anomalies (defined as above two standard deviations) to occur between the months of September and December (Extended Data Fig. 7a,b). The atmospheric pattern associated with these precipitation events exhibits a trough in the Gulf of Genoa region (Extended Data Fig. 7c), pointing to either increased cyclogenesis over or advection of North Atlantic low pressure into the western Mediterranean region.

The annual cycle of simulated Lake Ohrid precipitation in LOVECLIM is in good agreement with the reanalysis data; the model, however, underestimates the annual mean precipitation (Extended Data Fig. 8b). Maxima in our simulated precipitation time series (defined as above two standard deviations) indicate a positive anomaly from September to November (SON) in agreement with the reanalysis data (Fig. 3, Extended Data Fig. 8b). Despite important differences in the geographical expansion of geopotential height anomalies, both the NOAA and LOVECLIM data show pronounced troughs in the central Mediterranean area and an increase of rainfall during winter half-year in our focus region (Fig. 3). Our observations support previous modelling experiments suggesting that weakened atmospheric stratification and reduced hemispheric temperature contrasts ${ }^{2}$, in combination with an increased contrast between warm SST and lower continental air temperatures ${ }^{17}$, fuel precipitation increase in the Mediterranean. Such a preconditioning is particularly pronounced at the beginning of the fall, when the stronger thermal inertia of the sea relative to the land promotes local cyclogenesis ${ }^{17,29}$. Local cyclogenesis in combination with the southward shift in the $\mathrm{NH}$ atmospheric circulation cells during the winter half-year, which also favours a more southerly trajectory for storm tracks across the North Atlantic and into the Mediterranean ${ }^{2}$, lead to increased winter rainfall in the Mediterranean mid-latitudes. 
Owing to the significant positive correlation between the simulation and our proxy

221 time series (Extended Data Fig. 4), in terms of timing and amplitude, we infer that this

222 mechanism primarily controlled precipitation at Lake Ohrid for the last 1.36 Myr. Indeed,

223 similar to the NH summer monsoon records, we observe a strong influence of NHSI and a

224 reduced winter temperature contrast in the NH throughout the entirety of our multiproxy time

225 series, suggesting persistence of the mechanism during different climate boundary conditions.

226 The positive phase relationship between the Lake Ohrid precipitation proxy time series and

227 sapropel records (Fig. 2) indicates a strong coherence of African summer monsoon strength

228 and widespread Mediterranean winter half-year precipitation. Some peaks in our precipitation

229 proxy time series, which are not represented by sapropel layers (Fig. 2), may indicate lower

230 monsoon strength and reduced runoff from the African continent or that the general setting

231 required for sapropel deposition and preservation was not established in the Mediterranean

232 Sea during these periods ${ }^{15}$. During colder and drier glacial periods ${ }^{3}$ with increased global ice

233 volume, lower atmospheric $\mathrm{CO}_{2}$ concentrations, and stronger mid-latitude westerlies,

234 insolation forcing on precipitation appears suppressed in our record. This is in agreement with

235 the sensitivity simulations conducted to disentangle the individual effects of orbital forcing,

$236 \mathrm{NH}$ ice sheets, and $\mathrm{CO}_{2}$ on Lake Ohrid precipitation (Extended Data Fig. 6).

Precessional forcing on insolation is not only the key driver of the NH monsoons, it

238 also exerts a strong control on precipitation variability in the Mediterranean mid-latitudes

239 during the Quaternary. Lake Ohrid sediment cores record highly resolved and chronologically

240 well-constrained information on precipitation maxima during phases of lower

241 intrahemispheric temperature contrast and peak SST's over the last 1.36 Myr. The apparent

242 equivalence of the past regional key drivers of precipitation extremes to those produced by

243 continued anthropogenic increase of atmospheric GHG concentrations may help to reduce

244 simulation uncertainties and makes these results also relevant to predictions for the future

245 evolution of Mediterranean climate. 


\section{References:}

248 1. IPCC, 2013: Annex I: Atlas of Global and Regional Climate Projections [van

249 Oldenborgh, G. J., M. Collins, J. Arblaster, J. H. Christensen, J. Marotzke, S. B. Power, 250 M. Rummukainen and T. Zhou (eds.)]. In: Climate Change 2013: The Physical Sci $\neg$ ence Basis. Contribution of Working Group I to the Fifth Assessment Report of the Intergovernmental Panel on Climate Change [Stocker, T. F., D. Qin, G.-K. Plattner, M. Tignor, S. K. Allen, J. Boschung, A. Nauels, Y. Xia, V. Bex and P. M. Midgley (eds.)]. Cambridge University Press, Cambridge, United Kingdom and New York, NY, USA (2013).

2. Kutzbach, J. E., Chen, G., Cheng, H., Edwards, R. \& Liu, Z. Potential role of winter rainfall in explaining increased moisture in the Mediterranean and Middle East during periods of maximum orbitally-forced insolation seasonality. Clim. Dyn. 42, 1079-1095 (2014). doi:10.1007/s00382-013-1692-1

3. Tzedakis, P. C., Hooghiemstra, H. \& Pälike H. The last 1.35 million years at Tenaghi Philippon, revised chronostratigraphy and long-term vegetation trends. Quat. Sci. Rev. 25, 3416-3430 (2006). doi:10.1016/j.quascirev.2006.09.002

4. Hoerling, M. et al. On the increased frequency of Mediterranean drought. J. Climate 25, 2146-2161 (2012). doi:10.1175/JCLI-D-11-00296.1

5. Weisheimer, A. \& Palmer, T. N. On the reliability of seasonal climate forecasts. J. Royal Soc., Interface 11, 20131162 (2014). doi.org/10.1098/rsif.2013.1162

6. Totz, S., Tziperman, E., Coumou, D., Pfeiffer, K. \& Cohen, J. Winter Precipitation Forecast in the European and Mediterranean Regions Using Cluster Analysis. Geophys. Res. Lett. 44, 12,418-12,426 (2017). doi.org/10.1002/2017GL075674 
7. Milner, A. M. et al. Enhanced seasonality of precipitation in the Mediterranean during the early part of the Last Interglacial. Geology 40, 919-922 (2012). doi:10.1130/G33204.1

8. Toucanne, S. et al. Tracking rainfall in the northern Mediterranean borderlands during sapropel deposition. Quat. Sci. Rev. 129, 178-195 (2015).

$$
\text { doi:10.1016/j.quascirev.2015.10.016 }
$$

9. Stockhecke, M. et al. Millennial to orbital-scale variations of drought intensity in the Eastern Mediterranean. Quat. Sci. Rev. 133, 77-95 (2016). doi: 10.1016/ j.quascirev.2015.12.016

10. Roberts, N. et al. Stable isotope records of Late Quaternary climate and hydrology from Mediterranean lakes: the ISOMED synthesis. Quat. Sci. Rev. 27, 2426-2441 (2008). doi:10.1016/j.quascirev.2008.09.005

11. Magny, M. et al. North-south palaeohydrological contrasts in the central Mediterranean during the Holocene: tentative synthesis and working hypotheses. Clim. Past 9, 2043-2071 (2013). doi:10.5194/cp-9-2043-2013

12. Emeis K.-C., Camerlenghi A., McKenzie J. A., Rio D.\& Sprovieri R., The occurrence and significance of Pleistocene and Upper Pliocene sapropels in the Tyrrhenian Sea. Mar. Geol. 100, 155-182 (1991). doi:10.1016/0025-3227(91)90231-R

13. Kroon, D. al. Oxygen isotope and sapropel stratigraphy in the Eastern Mediterranean during the last 3.2 million years, in Proceedings of the Ocean Drilling Program. Scientific results, A. H. F. Robertson, K.-C. Emeis, C. Richter, A. Camerlenghi. Eds. (College Station, Texas, 1998), vol. 160, pp 181-190 (1998).

14. Rossignol-Strick, M. Mediterranean Quaternary sapropels, an immediate response of the African monsoon to variation of insolation. Palaeogeogr. Palaeoclimatol. Palaeoecol. 49, 237-263 (1985). doi:10.1016/0031-0182(85)90056-2 
15. Rohling, E. J., Marino, G. \& Grant, K. M. Mediterranean climate and oceanography, and the periodic development of anoxic events (sapropels). Earth Sci. Rev. 143, 62-97 (2015). doi:10.1016/j.earscirev.2015.01.008

16. Tzedakis, P. C. Seven ambiguities in the Mediterranean palaeoenvironmental narrative. Quat. Sci. Rev. 26, 2042-2066 (2007). doi:10.1016/j.quascirev.2007.03.014

17. Bosmans, J. H. C. et al. Precession and obliquity forcing of the freshwater budget over the Mediterranean. Quat. Sci. Rev., 123, 16-30 (2015). doi:10.1016/j.quascirev.2015.06.008

18. Wagner, B. et al. The environmental and evolutionary history of Lake Ohrid (FYROM/Albania): Interim results from the SCOPSCO deep drilling project. Biogeosciences 14, 2033-2054 (2017). doi:10.5194/bg-14-2033-2017

19. Vogel, H., Wagner, B., Zanchetta, G., Sulpizio, R. \& Rosén, P. A paleoclimate record with tephrochronological age control for the last glacial-interglacial cycle from Lake Ohrid, Albania and Macedonia. J. Paleolimnol. 44, 295-310 (2010).

20. Francke, A. et al. Sedimentological processes and environmental variability at Lake doi:10.1007/s 10933-009-9404-x

$$
\text { Ohrid (Macedonia, Albania) between } 637 \mathrm{ka} \text { and the present. Biogeosciences 13, }
$$

$$
\text { 1179-1196 (2016). doi:10.5194/bg-13-1179-2016 }
$$

21. Forner, A. et al. Extreme droughts affecting Mediterranean tree species' growth and water-use efficiency: the importance of timing. Tree Physiol. 38, 1127-1137 (2018). doi:10.1093/treephys/tpy022 climate sensitivity and its implications for future greenhouse warming. Sci. Adv. 2 (2016), p. e1501923. doi:10.1126/sciadv.1501923 
23. Timmermann, A. \& Friedrich, T. Late Pleistocene climate drivers of early human migration. Nature 538, 92-95 (2016). doi:10.1038/nature19365

24. Lisiecki, L. E. \& Raymo, M. E. A Pliocene-Pleistocene stack of 57 globally distributed benthic $\delta^{18} \mathrm{O}$ records. Paleoceanography 20, PA1003 (2005). doi:10.1029/2004PA001071

25. Cheng, $\mathrm{H}$. et al. The Asian monsoon over the past 640,000 years and ice age terminations. Nature 534, 640-646 (2016). doi:10.1038/nature18591

26. Konijnendijk, T. Y. M., Ziegler, M. \& Lourens, L. J. Chronological constraints on Pleistocene sapropel depositions from high-resolution geochemical records of ODP Sites 967 and 968. Newslett. Stratigr. 47, 263-282 (2014). doi:10.1127/0078-0421/2014/0047

27. Colleoni, F., Masina, S., Negri, A. \& Marzocchi, A. Plio-Pleistocene high-low latitude climate interplay: a Mediterranean point of view. Earth Planet. Sci. Lett. 319-320, 35-44 (2012). doi:10.1016/j.eps1.2011.12.020

28. Martrat, B., Jimenez-Amat, P., Zahn, R. \& Grimalt J. O., Similarities and dissimilarities between the last two deglaciations and interglaciations in the North Atlantic region. Quat. Sci. Rev. 99, 122-134 (2014). doi:10.1016/j.quascirev.2014.06.016

29. Trigo, R. M., Osborne, T. J. \& Corte-Real, J. M. The North Atlantic Oscillation influence on Europe: climate impacts and associated physical mechanisms. Clim. Res. 20, 9-17 (2002). doi:10.3354/cr020009

30. Laskar, J. et al. A long-term numerical solution for the insolation quantities of the earth. Astron. Astrophys. 428, 261-285 (2004). doi:10.1051/0004-6361:20041335 
Acknowledgments: The Hydrobiological Institute in Ohrid (S. Trajanovski and G. Kostoski)

342 and the Hydrometeorological Institute in Tirana (M. Sanxhaku and B. Lushaj) provided

343 logistic support for site surveys and the scientific drilling campaign. Drilling was carried out

344 by Drilling, Observation and Sampling of the Earth's Continental Crust (DOSECC). A.

345 Skinner provided logistic and technical advice prior and during drilling operation. The

346 Scientific Collaboration on Past Speciation Conditions in Lake Ohrid (SCOPSCO) drilling

347 project was funded by the International Continental Scientific Drilling Program (ICDP), the

348 German Ministry of Higher Education and Research, the German Research Foundation, the

349 University of Cologne, the British Geological Survey, the INGV and CNR (both Italy), and

350 the governments of the republics of North Macedonia and Albania. V. Scao collected the V5

351 tephra, which was ${ }^{40} \mathrm{Ar} /{ }^{39} \mathrm{Ar}$ dated with funding from LEFE "INTERMED" grant (CNRS-

352 INSU) to S. Nomade.

353

354 Author Contributions: B Wagner and H Vogel designed the study and contributed equally.

355 BW initiated and coordinated the SCOPSCO drilling project and drilling campaign. HV

356 conceived major scientific ideas of this study. A Francke (sedimentology, chronology), T

357 Friedrich (LOVECLIM modelling), T Donders (palynology), J Lacey (isotope geochemistry),

358 and L Sadori (palynology) contributed and oversaw key datasets used in the study. They

359 coordinated together with F Cremer-Wagner, M Leng, E Regattieri, T Wilke and G Zanchetta

360 discussion and interpretations of proxy data groups and model results. Specific data were

361 provided by A Bertini (pollen, MIS 19-21, MIS 25-28, MIS 42-43), N Combourieu-Nebout

362 (pollen, MIS 1-4, MIS 8, MIS 14-15), B Giaccio (tephrostratigraphy), S Joannin (pollen,

363 MIS 1-4, MIS 13-16, MIS 30), J Just (paleomagnetic data), K Kouli (pollen, MIS 6-8, MIS

364 10, MIS 16-19, MIS 28-30, MIS 33), I Kousis (pollen, MIS 11-12, MIS 15), A

365 Koutsodendris (pollen, MIS 11-12, MIS 15), N Leicher (tephrostratigraphy), A Masi (pollen, 
MIS 5-6, MIS 20-25, MIS 31-32), A M Mercuri (pollen, MIS 6, MIS 34), S Nomade

367 (tephrochronology), N Nowaczyk (paleomagnetic data), K Panagiotopoulos (pollen, MIS 7-8,

368 MIS 35-43), O Peyron (pollen, MIS 1-4, MIS 13-16, MIS 30), L Sagnotti (paleomagnetic

369 data), G Sinopoli (pollen, MIS 5-6), R Sulpizio (tephrostratigraphy) and P Torri (pollen MIS

370 6, MIS 34). S Krastel, K Lindhorst, and T Wonik coordinated the seismic survey of Lake

371 Ohrid, the selection of the coring location and the geophysical measurements needed for core

372 correlation. A Grazhdani, M Melles, J Reed, and Z Levkov contributed to the conception of

373 the work. A Cvetkoska, J Holtvoeth, E Jovanvoska, S Tofilovska, and X Zhang provided

374 micropaleontological and organic geochemistry data, which confirmed that the sediment

375 succession from the DEEP site covers the entire history of Lake Ohrid. A Timmermann

376 provided model infrastructure and resources. All authors contributed to the discussion and

377 interpretation of the data and provided comments and suggestions to the manuscript.

Author Information: Reprints and permissions information is available at

www.nature.com/reprints. Authors declare no competing interests. Correspondence and

requests for materials should be addressed to wagnerb@uni-koeln.de. Data are available in

382 the main text, in the supplementary materials and in the Pangaea database at https://doi.pangaea.de/10.1594/PANGAEA.896848. Data used for LOVECLIM are available at https://climatedata.ibs.re.kr/grav/data/loveclim-784k.

Figure legends:

Fig. 1. Chronology and location of the Lake Ohrid DEEP site record. (a) The age model is based on tephrostratigraphic correlation of 16 tephra layers to their radiometrically dated 
second-order tie points), and cross evaluation of two paleomagnetic age reversals (a; dashed lines). The age model was calculated following the methodological approach for the upper 247 meters composite depth (mcd) of the record ${ }^{20}$ (see Methods). For the ages and errors of the tephra layers, see Extended Data Table 1. The tuning points (green) include an error of $\pm 2,000$ years. (c) The insert shows the location of Lake Ohrid and the approximate position of the intertropical convergence zone (ITCZ) in summer and winter.

\section{Fig. 2. Lake Ohrid precipitation indicators and global monsoon records for the last 1.4} million years. (a) Eastern Mediterranean $(E M)$ Sapropel ages $($ green $=$ sapropel, red $=$ red interval/oxidized sapropel, violet $=$ ghost sapropel $)^{12,13,27}$; (b) Chinese Speleostack $\delta^{18} \mathrm{O}^{26}$ in \%o relative to VPDB; (c) Medstack $\delta^{18} \mathrm{O}$ planktonic ${ }^{28}$ in \%o relative to VPDB; SST=seasurface temperature, $\mathrm{SSS}=$ sea-surface salinity; (d) Lake Ohrid $\delta^{13} \mathrm{C}$ endogenic calcite in \%o relative to VPDB; (e) Lake Ohrid deciduous oaks pollen percentage; (f) Lake Ohrid total inorganic carbon (TIC) concentrations; (g) Northern Hemisphere winter insolation difference between the tropic of cancer and the arctic $\operatorname{circle}^{30}$; (h) annual mean precipitation amount for the Lake Ohrid grid cell from the LOVECLIM simulation; (i) Lake Ohrid arboreal pollen excluding Pinus pollen (AP-P) percentages. Tenaghi Philippon arboreal pollen (AP) percentages $^{3}(\mathbf{k})$ and LR04 benthic $\delta^{18} \mathrm{O}$ stack $^{25}$ in \%o relative to VPDB with odd numbers for interglacials (1) are shown for comparison. Red and white diamonds indicate the position of radiometrically dated tephra layers, blue and white diamonds the position of reversals of Earth's magnetic field in the Lake Ohrid sediment record.

Fig. 3. Simulated Lake Ohrid precipitation and atmospheric anomaly pattern associated with precipitation maxima. (a) Simulated precipitation $\left(\mathrm{cm} \mathrm{yr}^{-1}\right)$ for the Lake Ohrid grid cell. Data based on 1,000-year averages. Dashed line indicates two standard deviations above the mean. Red shading highlights precipitation values exceeding two standard deviations. See Methods for details on the model simulations. (b) Composite anomalies of September- 
416 November (SON), $800 \mathrm{hPa}$ geopotential height (m, shading) and wind ( $\mathrm{m} \mathrm{s}^{-1}$, vectors)

417 associated with precipitation maxima shown in (a).

418

419

420

421

422 
Methods:

\section{$424 \quad$ Lake and lake hydrology}

425 Lake Ohrid $\left(41^{\circ} 02^{\prime} \mathrm{N}, 20^{\circ} 43^{\prime} \mathrm{E}, 693 \mathrm{~m}\right.$ a.s.l.; Fig. 1c) is located in the sub-Mediterranean

426 climate zone with average monthly air temperature ranging from $+26^{\circ} \mathrm{C}$ during summer to -

$427 \quad 1^{\circ} \mathrm{C}$ during winter. Precipitation in the Lake Ohrid watershed increases from 698 to $1,194 \mathrm{~mm}$

$428 \mathrm{yr}^{-1}$ with increasing altitude and occurs primarily during winter months $\mathrm{s}^{31}$. The lake is $\sim 30 \mathrm{~km}$

429 long, $\sim 15 \mathrm{~km}$ wide, and has a maximum water depth of $293 \mathrm{~m}$ (Extended Data Fig. 1).

430 Sublacustrine karst springs (55\%), direct precipitation, and river inflow (45\%) constitute the

431 water input. Due to an oligotrophic state, bottom waters remain partly oxygenated for several

432 years, although the lake is oligomictic and a complete overturn occurs only every few years at 433 present $^{32}$.

\section{Sediment cores}

436 Sediment cores from the Lake Ohrid DEEP site were recovered in spring 2013, using the 437 Deep Lake Drilling System (DLDS) of Drilling, Observation and Sampling of the Earth's

438 Continental Crust (DOSECC) and within the framework of the multinational and

439 interdisciplinary Scientific Collaboration on Past Speciation Conditions in Lake Ohrid

440 (SCOPSCO) project that was co-sponsored by the International Continental Scientific Drilling

441 Program (ICDP). The composite sediment record is based on 6 parallel boreholes that reached 442 a terminal depth of $568 \mathrm{~m}^{33}$. Sediment recovery from 0 to $456.1 \mathrm{~m}$ composite depth (mcd) is $44399.8 \%$. Small gaps occur between 204.719 and $204.804 \mathrm{mcd}(8.5 \mathrm{~cm})$ and between 447.89 444 and $448.19 \mathrm{mcd}(30 \mathrm{~cm})^{33}$. Mass movement deposits $(<3 \mathrm{~cm})$ occur between 117 and 107 $445 \mathrm{mcd}$, and between 55 and $50 \mathrm{mcd}$. Subsampling in the upper $447.12 \mathrm{mcd}$ excluded mass 446 movement and tephra deposits. 
Scanning-XRF analysis was performed at the University of Cologne, Germany, on split core

450 surfaces at $2.5 \mathrm{~mm}$ increments and $10 \mathrm{~s}$ dwell time using an ITRAX XRF core scanner (Cox

451 Analytics) equipped with an energy dispersive silicon drift detector and a Cr-tube set to 30

$452 \mathrm{kV} / 30 \mathrm{~mA}$. Raw data were processed and element-specific photon energy peaks were

453 integrated in Q-spec (Cox Analytics).

\section{$455 \quad$ Elemental analysis}

456 Elemental analysis was performed on 16-cm-spaced samples (2794 samples, $480 \mathrm{yr}$ )

457 following freeze-drying and homogenization at the University of Cologne. For total carbon

458 (TC) and total inorganic carbon (TIC) measurements, an aliquot of $40 \mathrm{mg}$ of the homogenized 459 sample material was dispersed in $10 \mathrm{ml}$ deionized water. TC was determined at combustion of $460900^{\circ} \mathrm{C}$ and TIC was measured after treatment with $40 \% \mathrm{H}_{3} \mathrm{PO}_{4}$ at $160^{\circ} \mathrm{C}$ using a DIMATOC 461100 and a DIMATOC 200 (DIMATEC Corp., Germany). The total organic carbon (TOC) 462 content was calculated as the difference between TC and TIC.

\section{Fourier Transform Infrared Spectroscopy (FTIRS)}

465 Relative concentration changes for quartz were assessed using FTIRS, on samples spaced at $32 \mathrm{~cm}$ (1462 samples, 1,000 yr). Measurements were performed using a Bruker Vertex 70 equipped with a $\mathrm{IN}_{2}$-cooled MCT (mercury-cadmium-telluride) detector, a $\mathrm{KBr}$ beam splitter, and a HTS-XT accessory unit (multisampler) in an air-conditioned laboratory at the University of Bern, Switzerland. For this purpose, $11 \mathrm{mg}$ of each sample and $500 \mathrm{mg}$ of oven-

470 dried spectroscopic grade $\mathrm{KBr}\left(\mathrm{Uvasol}^{\circledR}\right.$, Merck Corp.) were homogenized and scanned 64

471 times at a resolution of $4 \mathrm{~cm}^{-1}$ (reciprocal centimetres) for the wavenumber range from 3,750

472 to $520 \mathrm{~cm}^{-1}$ in diffuse reflectance mode. Data processing encompassed a linear baseline

473 correction to remove baseline shifts and tilts by setting two points of the recorded spectrum to 474 zero $\left(3,750\right.$ and $\left.2,210-2,200 \mathrm{~cm}^{-1}\right)$. Peak areas diagnostic for symmetric stretching of $\mathrm{SiO}_{4}$ in 
quartz (778 and $798 \mathrm{~cm}^{-1}$ ), and representative for relative abundance ${ }^{34,35}$ were integrated

476 using the OPUS (Bruker Corp.) software package.

\section{Palynology processing and analysis}

479 Pollen analysis was carried out on sediment samples spaced at $64 \mathrm{~cm}(697$ samples, $\sim 2000 \mathrm{yr})$

480 following processing, identification, and counting approaches as described in ${ }^{36}$. Dry sediment 481 (1.0-1.5 g) samples were treated with cold $\mathrm{HCl}(37 \%$ vol), cold $\mathrm{HF}$ (40\%vol), and hot $\mathrm{NaOH}$ $482(10 \% \mathrm{vol})$ to dissolve carbonates, silicates, and humic acids, respectively. Glycerin-mounted 483 residues were analysed by transmitted light microscopy to a mean of $\sim 533$ (incl. Pinus) and $484 \sim 250$ (excl. Pinus) grains/sample. Relative abundances are based on the total terrestrial pollen 485 sum excl. Pinus due to overrepresentation and potential long-distance transport of this $486 \operatorname{taxon}^{36}$. Deciduous oak abundances represent the combined percentages of Quercus robur and Q. cerris types ${ }^{37}$, which is commonly used as an indicator for mid-elevation, relatively humid forest across the Mediterranean $38,39,40,41$.

\section{Isotope analysis}

491 Oxygen and carbon isotopes were analysed on bulk carbonate (calcite) ${ }^{42}$ in samples spaced at $16 \mathrm{~cm}$ through zones of higher TIC $(>0.5 \%)$, comprising a total of 1309 sediment samples.

493 The samples were immersed in $5 \% \mathrm{NaClO}$ solution for $24 \mathrm{~h}$ to gently disaggregate the 494 sediment and oxidize reactive organic material. Potential biogenic carbonate was removed by 495 sieving and the $<64 \mu \mathrm{m}$ fraction washed with deionized water, dried at $40^{\circ} \mathrm{C}$, and then ground 496 to a fine powder in an agate mortar. $\mathrm{CO}_{2}$ was evolved from $10 \mathrm{mg} \mathrm{CaCO}_{3}$ powders by reaction with anhydrous $\mathrm{H}_{3} \mathrm{PO}_{4}$ overnight inside a vacuum at a constant temperature of $25^{\circ} \mathrm{C}$.

498 The liberated $\mathrm{CO}_{2}$ was cryogenically purified under vacuum and collected for analysis on a 499 VG Optima dual inlet mass spectrometer. Oxygen and carbon isotope values are reported in 500 standard delta notation $\left(\delta^{18} \mathrm{O}_{\text {calcite }}\right.$ and $\delta^{13} \mathrm{C}_{\text {calcite, }}$, respectively) in per mille (\%o) calculated to 
501 the Vienna Pee Dee Belemnite (VPDB) scale using a within-run laboratory standard (MCS) calibrated against international NBS standards. Analytical reproducibility for the within-run standard was $<0.1 \%( \pm 1 \sigma)$ for $\delta^{18} \mathrm{O}$ and $\delta^{13} \mathrm{C}$.

\section{Magnetostratigraphic analyses}

506 Remanent magnetization in its natural state (NRM) and after step-wise alternating field

507 demagnetization (10 steps up to $100 \mathrm{mT}$ ) was measured on $\sim 900$ discrete cube $\left(6.3 \mathrm{~cm}^{3}\right)$

508 samples with an average 48-cm-spacing at the Paleomagnetic Laboratory at the

509 GeoForschungsZentrum, Potsdam, Germany, using a 2G Enterprises cryogenic

510 magnetometer. Paleomagnetic directions (declination and inclination) were calculated using

511 principle component analysis (PCA) after removal of low-coercivity magnetic overprints.

512 After identification of geomagnetic polarity transitions, $\sim 500$ additional samples were taken at

5132 to 3 -cm-spacing across these transitions for high-resolution analysis at the Istituto Nazionale

514 di Geofisica e Vulcanologia, Rome, Italy, using the same analytical set up and routine as in

515 Potsdam. As glacial intervals of the core contain diagenetically formed greigite, which

516 overprints the primary paleomagnetic signal ${ }^{43}$, paleomagnetic transitions are faithfully

517 preserved only in interglacial intervals, at the base of the Jaramillo sub-Chron (373.8 mcd)

518 and at the Matuyama/Brunhes (M/B) boundary $(287.6 \mathrm{mcd})$.

\section{Tephrostratigraphic analysis}

521 Eleven tephra and three cryptotephra layers have successfully been identified in the upper 247

522 mcd of the record ${ }^{44,45,46}$. Two additional tephra layers from the lower ( $>247 \mathrm{mcd}$ ) part of the

523 DEEP site record are introduced here. The tephrostratigraphic correlation of these tephras is

524 based on geochemical fingerprinting of single glass shards using Wavelength Dispersive

525 Electron Microprobe Analysis (WDS-EPMA) as described in ${ }^{44}$. 
${ }^{40} \mathrm{Ar} /{ }^{39} \mathrm{Ar}$ dating was performed at the LSCE facility (CEA, UVSQ and University

527 Paris-Saclay). V5 tephra (=OH-DP-2669 layer) was collected in Montalbano-Jonico

528 (Southern Italy, N40¹7’32.8' ' E16³3'27.4'’). Twenty pristine sanidine crystals, of the

529 fraction 0.6-1.0 mm, were extracted from V5 and irradiated for $2 \mathrm{~h}$ in the Cd-lined, in-core

530 CLICIT facility of the Oregon State University TRIGA reactor (Irradiation CO 001).

531 Subsequently, 14 crystals were individually loaded in a copper sample holder and put into a

532 double vacuum Cleartran window. Each crystal was individually fused using a Synrad $\mathrm{CO}_{2}$

533 laser at $10-15 \%$ of nominal power $(\sim 50 \mathrm{~W})$. The extracted gas was purified for 10 min by two

534 hot GP 110 and two GP 10 getters (ZrAl). Ar isotopes $\left({ }^{36} \mathrm{Ar},{ }^{37} \mathrm{Ar},{ }^{38} \mathrm{Ar},{ }^{39} \mathrm{Ar}\right.$ and $\left.{ }^{40} \mathrm{Ar}\right)$ were

535 analysed by mass spectrometry using a VG5400 equipped with an electron multiplier Balzers

536217 SEV SEN coupled to an ion counter. Neutron fluence $J$ for each sample is calculated

537 using co-irradiated Alder Creek Sanidine (ACs-2) standard with an age of $1.1891 \mathrm{Ma}^{47}$ and

538 the total decay constant of ${ }^{48}$. J-values computed from standard grains is $0.00053220 \pm$

5390.00000160 . Mass discrimination was estimated by analysis of air pipette throughout the

540 analytical period, and was relative to ${ }^{40} \mathrm{Ar} /{ }^{36} \mathrm{Ar}$ ratio of $298.56{ }^{49}$.

541 Tephra OH-DP-2669 is a $2.5 \mathrm{~cm}$ thick, yellowish layer with sharp upper and lower

542 boundaries comprising up to $500 \mu \mathrm{m}$ large platy glass shards and minor elongated

543 micropumices. Its distinct trachytic composition (Extended Data Fig. 2) and the stratigraphic

544 position between the M/B boundary (287.6 mcd) and OH-DP-2060 (Tufo di Bagni Albula,

$545524.84 \mathrm{ka}^{44}$; Extended Data Table1) narrow potential tephrostratigraphic equivalents. Tephra

546 layer SC1-35.30/SUL2-1 from the Sulmona basin in the Italian Apennines is the only tephra

547 with a similar trachytic composition ${ }^{50,51}$ for this interval (Extended Data Fig. 2, Extended

548 Data Table 2). SC1-35.30/SUL2-1 was correlated with tephra V5 from the MJS ${ }^{52,53}$. The

549 majority of the SC1-35.30/SUL2-1 and OH-DP-2669 analyses correlate well with the more

550 evolved group of V5 (V5b: $\mathrm{SiO}_{2}>63 \%$ wt.; $\mathrm{CaO}<1.5 \%$ wt.). Only few analyses plot in the

551 field of the less evolved group V5a (Extended Data Fig. 2, Extended Data Table 2). Tephra 
552 layer SUL2-1 and V5 were ${ }^{40} \mathrm{Ar} /{ }^{39} \mathrm{Ar}$ dated at $722.8 \pm 2.4 \mathrm{ka}^{50}$ and $719.5 \pm 12.6 \mathrm{ka}^{53}$,

553 respectively.

554 The previous proposed correlation of SUL2-1/V5 with the Parmenide ash found in the

555 Crotone basin ${ }^{50,52}$ is not considered here due to a slightly younger ${ }^{40} \mathrm{Ar} /{ }^{39} \mathrm{Ar}$ age of the

556 Parmenide ash $(710 \pm 5 \mathrm{ka})^{54,55,56}$ and the differences in the geochemical data to OH-DP-2669

557 (Extended Data Fig. 2, Extended Data Table 2).

558 Tephra OH-DP-2898 is a $\sim 0.8 \mathrm{~cm}$ thick, whitish-yellowish band of lenses comprising

559 fine-grained glass shards with a high degree of vesicularity and a phonolitic composition

560 (Extended Data Fig. 2). It is located $\sim 2 \mathrm{~m}$ below the M/B boundary, in calcareous sediments

561 indicative for interglacial conditions ${ }^{20}$. The comparison of OH-DP-2898 glass composition

562 with those of Sulmona tephra SUL2-19, -20, -25, -29 and -31 in a similar

563 magnetostratigraphic position exclude a correlation (Extended Data Fig. 2). Other Sulmona

564 tephra close to the M7B transition, SUL2-22, -23, and -27, have a composition similar to OH-

565 DP-2898, but SUL2-23 has slightly lower alkali and higher $\mathrm{CaO}, \mathrm{FeO}, \mathrm{TiO}_{2}$ concentrations

566 (Extended Data Fig. 2, Extended Data Table 2). SUL2-27 is geochemically indistinguishable

567 from OH-DP-2898, but deposited in glacial sediments of the MIS $20^{57}$. SUL2-22 is also

568 geochemically indistinguishable from OH-DP-2898 and shares a similar stratigraphic position

569 below the M/B boundary ${ }^{58,59}$ and at the transition from MIS 20 to MIS $19^{57}$. A correlation of

570 OH-DP-2898 with tephra V4 from the MJS is not possible due to differences in the

571 compositional range (Extended Data Fig. 2, Extended Data Table 2) and a younger ${ }^{40} \mathrm{Ar} /{ }^{39} \mathrm{Ar}$

572 age of $773.9 \pm 1.3 \mathrm{ka}$ of $\mathrm{V} 4{ }^{52}$, quasi-synchronous position during the ${ }^{10} \mathrm{Be}$ peak or $\mathrm{M} / \mathrm{B}$

573 transition $^{60}$. Also a correlation of OH-DP-2898/SUL2-22 with tephra V3 of the MJS

$574(801.2 \pm 19.5 \mathrm{ka})$ is excluded due to differences in the geochemical composition (Extended

575 Data Fig. 2, Extended Data Table 2) and deposition of V3 during glacial conditions of MIS 20

$576{ }^{60}$. The Pitagora ash from the Crotone basin is found in a similar magneto- and

577 climatostratigraphic position ${ }^{55,61,62}$, but differs geochemically from OH-DP-2898/SUL2-22. 
Therefore, we regard a correlation of OH-DP-2898 with SUL2-22 as most robustly and use its ${ }^{40} \mathrm{Ar} /{ }^{39} \mathrm{Ar}$ age of $791.9 \pm 1.9 \mathrm{ka}{ }^{58}$ for our chronology. In addition to the new tephra correlations, we updated ages for the upper tephra layers

581 (Extended Data Table 1). This update includes the Campanian Ignimbrite (Y-5/OH-DP0169) ${ }^{63}$ and tephra layers OH-DP-0404/POP2 and OH-DP-0435/X-6, based on new results

583 from the Sulmona section ${ }^{64}$. The tephrostratigraphy of the Fucino record ${ }^{65}$ improved and 584 reassessed the correlations established for OH-DP-0617 and OH-DP-0624 ${ }^{44} \cdot{ }^{40} \mathrm{Ar} /{ }^{39} \mathrm{Ar}$ dating of TF-17, correlated to OH-DP-0624, yielded a much more precise age of $158.8 \pm 3.0 \mathrm{ka}$, which replaced the age of Vico B/OH-DP-0617 (162 $\pm 6 \mathrm{ka})^{66}$. provided a new chronological tie-point at $410 \pm 2 \mathrm{ka}^{67}$. The previously established correlation of tephra layer OH-DP-1955 with tephra layer SC-5 from the Mercure basin ${ }^{44}$ was rejected in the light of its large uncertainty $( \pm 10.9 \mathrm{ka})$ and the new tephrostratigraphic data. DP-2669, by updating the value of the atmospheric Ar-composition $\left({ }^{40} \mathrm{Ar} /{ }^{36} \mathrm{Ar}: 298.5\right.$ instead of 295.5 originally) and removing xenocrysts ${ }^{58}$ yielded a new age of $715.02 \pm 5.4$ ka (Extended Data Table 1) using the decay constant of ${ }^{48}$ and an age of 1.1891 Ma for the ACs-2 flux standard ${ }^{47}$. Our new ${ }^{40} \mathrm{Ar} /{ }^{39} \mathrm{Ar}$ age of V5 $(716.2 \pm 5.4 \mathrm{ka} ; \mathrm{MSWD}=0.8, \mathrm{P}=0.7)$ is undistinguishable within uncertainty and thus used for our chronology. All other ${ }^{40} \mathrm{Ar} /{ }^{39} \mathrm{Ar}$ used were recalculated using the software $\operatorname{ArAR}^{68}$ with a given decay constant and age for ACs-2 (1.1891 Ma) and Fish Canyon sanidines (FCs) ages of 28.294 Ma.

\section{Chronology}

601 Following the methodological approach for the upper $247 \mathrm{mcd}$ of the record ${ }^{20}$, the chronology 602 of the DEEP site sediment succession down to 447.12 mcd uses tephrochronological data ${ }^{44,45}$, $603{ }^{46}$ as $1^{\text {st }}$-order tie points and tuning of climate-sensitive proxy data (TOC; 480 yr resolution) 
604 against orbital parameters as $2^{\text {nd }}$-order tie points considering that maxima in TIC represent

605 interglacial periods ${ }^{19,20}$. Some chronologically well-constrained tephra layers deposited at the

606 DEEP site since the penultimate glacial period (Y-5, X-6, P-11, and A11/12) occur at depths

607 where TOC shows minima at times of the perihelion passage in $\mathrm{March}^{20}$. These perihelion

608 passages in March correspond to the inflection points of increasing local summer insolation

609 (21 ${ }^{\text {st }}$ June) and winter-season length (number of days between the September and March

610 equinoxes) at the latitude of Lake Ohrid ( $41^{\circ} \mathrm{N}$; Fig. 1). Increasing summer insolation

611 promotes high summer temperatures, primary productivity in the water column and increases

612 organic matter (OM) supply to the sediments. An extended winter season improves lake-water

613 mixing which enhances oxidation of $\mathrm{OM}$ in the water column and the surface sediments ${ }^{20}$.

614 Thus, minima in TOC result from moderate OM supply to the sediments and improved

615 oxidation of $\mathrm{OM}$ at the sediment surface and are due to their available high temporal

616 resolution in the DEEP site record used for tuning purposes.

The independent chronological information obtained from the 16 tephra and

618 cryptotephra layers and $662^{\text {nd }}$-order tie points obtained from orbital tuning were cross

619 evaluated by the two paleomagnetic age constraints (base of the Jaramillo sub-Chron and

620 Matuyama/Brunhes M/B; Fig. 1). The age model was calculated using Bacon $2.2^{69}$,

621 considering overall uniform (mem.strength $=60$, mem.mean $=0.9$, thick $=80 \mathrm{~cm}$ ) sedimentation

622 rates (acc.shape $=1.5$, acc. mean $=20$ ) at the DEEP $\operatorname{sit}^{33}$. An error of $\pm 2,000$ years was applied

623 to the $2^{\text {nd }}$-order tie points to account for tuning inaccuracy. The $95 \%$ confidence intervals of

624 ages for specific depths produced by the Bacon Bayesian age modelling average at $\pm 5,500$

625 years with a maximum of $\pm 10,680$ years. The resulting chronology implies that the upper

$626447.12 \mathrm{~m}$ of the DEEP site record covers the last $1.364 \mathrm{Myr}$, continuously.

$627 \quad \mathrm{We}^{20}$ evaluated the DEEP site's chronology against the 0-160 ka U/Th dated Soreq

628 Cave speleothem record ${ }^{70}$ and found agreement within errors of the chronologies. Arboreal 
pollen (AP) percentages in the DEEP site record are also in agreement with those from the

630 orbitally-tuned Tenaghi Philippon record ${ }^{3}$ back to $1.364 \mathrm{Ma}$ (Fig. 2).

631

632

Model simulations and forcing

633 Transient simulations with the Earth system model LOVECLIM were conducted to study the

634 impacts of orbital forcing, Northern Hemisphere $(\mathrm{NH})$ ice sheets, and variations in

635 atmospheric greenhouse gases (GHGs) on glacial-interglacial climate change.

636

LOVECLIM is a coupled ocean-atmosphere-sea ice-vegetation model ${ }^{71}$. The

637 atmospheric component of LOVECLIM is the spectral T21, three-level model ECBilt ${ }^{72}$ based

638 on quasi-geostrophic equations extended by estimates of ageostrophic terms. The ocean-sea

639 ice component of LOVECLIM consists of a free-surface Ocean General Circulation Model

640 with a $3^{\circ} \times 3^{\circ}$ horizontal resolution coupled to a dynamic-thermodynamic sea-ice model $1^{73}$.

641 Atmosphere and ocean components are coupled through the exchange of freshwater and heat

642 fluxes. The vegetation model $\mathrm{VECODE}^{74}$ computes the evolution of terrestrial vegetation

643 cover based on annual mean surface temperature and precipitation.

644 The transient simulations of the last 784,000 years were forced by time-dependent

645 boundary conditions for orbital parameters, atmospheric GHG concentrations, NH ice sheet

646 orography, and albedo following the methodology described in ${ }^{75}$. The orbital forcing was

647 calculated according to ${ }^{76}$. Atmospheric GHG concentrations were prescribed according to

648 reconstructions from EPICA Dome $\mathrm{C}$ for $\mathrm{CO}_{2}{ }^{77}$ as well as $\mathrm{CH}_{4}$ and $\mathrm{N}_{2} \mathrm{O}^{78}$. Orbital forcing and

649 atmospheric GHG concentrations were updated every model year. The effects of NH ice

650 sheets on albedo and land topography were prescribed according to ${ }^{79}$. The forcing was applied

651 with an acceleration factor of 5, which compresses 784,000 forcing years into 156,000 model

652 years. This acceleration factor is appropriate for quickly equilibrating surface variables. The

653 model simulation is an updated version of the one presented in $^{75}$ and uses a higher climate 
654

655

656

657

658

659

660

661

662

663

664

665

666

667

668

669

670

671

672

673

674

675

676

677

678

sensitivity resulting in a better representation of the glacial-interglacial surface temperature amplitude ${ }^{23}$.

Four sensitivity simulations were conducted in addition to the full-forcing simulation described above (Extended Data Fig. 6). The sensitivity simulations cover the last four glacial cycles (408,000 years) and aim at exploring the individual effects of atmospheric GHGs, $\mathrm{NH}$ ice sheets and orbital parameters to glacial-interglacial climate change. The first sensitivity simulation uses transient forcing as described above but constant preindustrial (PI) atmospheric GHG concentrations. The "GHG effect" can then be calculated as the difference between the simulation using the full forcing and this simulation. The second sensitivity simulation uses transient forcing as described above but constant PI NH ice sheets (extent and albedo). The "NH ice sheet effect" is calculated as the difference between the full-forcing simulation and this simulation. Two simulations were designed to study the role of orbital forcing under warm and cold climate. For both simulations, transient orbital parameters are used. However, one simulation was run under constant PI atmospheric $\mathrm{CO}_{2}$ concentration of 280 ppm, whereas the second simulation uses a constant atmospheric $\mathrm{CO}_{2}$ concentration of 200 ppm resulting in a colder background climate.

\section{Data analysis}

To assess the temporal evolution of dominant periodicities in the DEEP site TIC and deciduous oak pollen percentage data, a wavelet power spectrum was computed for the respective time series. The time series were resampled at regular intervals (linear interpolation) at $0.3 \mathrm{kyr}$ (TIC) and $1.0 \mathrm{kyr}$ (pollen), and subsequently submitted to continuous wavelet transform (CWT, Morlet window) using PAST v.3.21 software ${ }^{80}$ following the approach by ${ }^{81}$. Results of the CWT show persistent presence of $100 \mathrm{kyr}$ and $\sim 21 \mathrm{kyr}$ orbital frequencies, and a clear presence of $41 \mathrm{kyr}$ in the early half of the pollen record. Relative to 
679

680

681

682

683

684

685

686

687

688

689

690

691

692

693

694

695

696

697

698

699

700

701

the pollen, the CWT results of the TIC show a more pronounced $100 \mathrm{kyr}$ cyclicity over the entire record, and less pronounced 21 kyr signals.

To quantitatively test the observed correlation between deciduous oak and TIC maxima against precession forcing, the bandpass-filtered 18-25 kyr component of the proxy data was regressed against precession based on the La2004 orbital solution ${ }^{30}$.

Partial least squares regression (PLSR) was used to test the correlation of TIC and deciduous oaks as predictive variables with LOVECLIM temperature and precipitation output data. PLSR was performed using SIMCA 14 (Sartorius Stedim Biotech). All datasets were filtered using a frequency centred at 0.05 and a bandwidth of 0.02 prior to multivariate statistical analysis to accommodate for slight age offsets between proxy and simulation data.

\section{Methods and Extended Data files references:}

31. Popovska, C. \& Bonacci, O. Basic data on the hydrology of Lakes Ohrid and Prespa. Hydrol. Process. 21, 658-664 (2007). doi:10.1002/hyp.6252

32. Matzinger, A., Spirkovski, Z., Patceva, S. \& Wüest A. Sensitivity of ancient Lake Ohrid to local anthropogenic impacts and global warming, J. Great Lakes Res. 32, 158-179 (2006). doi:10.3394/0380-1330(2006)32[158:SOALOT]2.0.CO;2

33. Wagner, B. et al. The SCOPSCO drilling project recovers more than 1.2 million years of history from Lake Ohrid. Sci. Drill. 17, 19-29 (2014). doi:10.5194/sd-17-19-2014

34. Farmer, V. C. The infrared spectra of minerals, edited by: V. C. Farmer, Mineralogical Society Monograph 4, 227 pp, Adlard \& Son, Dorking, Surrey, (1974).

35. Chukanov, N. V. Infrared Spectra of Mineral Species. Springer, Dordrecht, Heidelberg, New York, London (2014). doi:10.1007/978-94-007-7128-4 
36. Sadori, L. et al. Pollen-based paleoenvironmental and paleoclimatic change at Lake Ohrid (south-eastern Europe) during the past 500 ka. Biogeosciences 13, 1423-1437 (2016). doi:10.5194/bg-13-1423-2016

37. Beug, H.-J. Leitfaden der Pollenbestimmung für Mitteleuropa und angrenzende Gebiete. Verlag Dr. Friedrich Pfeil, München, Germany (2004).

38. Cheddadi, R. et al. Imprints of glacial refugia in the modern genetic diversity of Pinus sylvestris. Global Ecol. Biogeogr. 15, 271-282 (2006). doi:10.1111/j.14668238.2006.00226.x

39. Rossignol-Strick, M. The Holocene climatic optimum and pollen records of sapropel 1 in the Eastern Mediterranean, 9000-6000 BP. Quat. Sci Rev. 18, 515-530 (1999). doi:10.1016/S0277-3791(98)00093-6

40. Langgut, D., Almogi-Labin, A., Bar-Matthews, M. \& Weinstein-Evron, M. Vegetation and climate changes in the South Eastern Mediterranean during the Last GlacialInterglacial cycle (86 ka): new marine pollen record. Quat. Sci Rev. 30, 3960-3972 (2011). doi:10.1016/j.quascirev.2011.10.016

41. Combourieu-Nebout, N. et al. Climate changes in the central Mediterranean and Italian vegetation dynamics since the Pliocene. Rev. Palaeobot. Palynol. 218, 127-147 (2015). doi:10.1016/j.revpalbo.2015.03.001

42. Lacey, J. H. et al. Northern Mediterranean climate since the Middle Pleistocene: a 637 ka stable isotope record from Lake Ohrid (Albania/Macedonia). Biogeosciences 13, 1801-1820 (2016). doi:10.5194/bg-13-1801-2016

43. Just, J. et al. Environmental control on the occurrence of high-coercivity magnetic minerals and formation of iron sulfides in a $640 \mathrm{ka}$ sediment sequence from Lake Ohrid (Balkans). Biogeosciences 13, 2093-2109 (2016). doi:10.5194/bg-13-2093-2016 
44. Leicher, N. et al. First tephrostratigraphic results of the DEEP site record from Lake Ohrid (Macedonia and Albania). Biogeosciences 13, 2151-2178 (2016). doi:10.5194/bg$13-2151-2016$

45. Kousis, I. et al. Centennial-scale vegetation dynamics and climate variability in SE Europe during Marine Isotope Stage 11 based on a pollen record from Lake Ohrid. Quat. Sci. Rev. 190, 20-38 (2018). doi:10.1016/j.quascirev.2018.04.014

46. Francke, A. et al. Sediment residence time reveals Holocene shift from climatic to vegetation control on catchment erosion in the Balkans. Global Planet. Change 177, 186-200. 2019. doi:10.1016/j.gloplacha.2019.04.005

47. Niespolo, E. M., Rutte, D., Deino, A. L. \& Renne, P. R. Intercalibration and age of the Alder Creek sanidine ${ }^{40} \mathrm{Ar} /{ }^{39} \mathrm{Ar}$ standard. Quat. Geochronol. 39, 205-213 (2017). doi:10.1016/j.quageo.2016.09.004

48. Renne, P. R., Balco, G., Ludwig, K. R., Mundil, R. \& Min, K. Response to the comment by W. H. Schwarz et al. on "Joint determination of ${ }^{40} \mathrm{~K}$ decay constants and ${ }^{40} \mathrm{Ar} * /{ }^{40} \mathrm{~K}$ for the Fish Canyon sanidine standard, and improved accuracy for ${ }^{40} \mathrm{Ar} /{ }^{39} \mathrm{Ar}$ geochronology" by P. R. Renne et al. (2010). Geochim. Cosmochim. Acta 75, 5097-5100 (2011). doi:10.1016/j.gca.2010.06.017

49. Lee, J. Y. et al. A redetermination of the isotopic abundances of atmospheric Ar. Geochim. Cosmochim. Acta 70, 4507-4512 (2006). doi:10.1016/j.gca.2006.06.1563

50. Giaccio, B. et al. Revised Chronology of the Sulmona Lacustrine Succession, Central Italy. J. Quat. Sci. 28, 545-551 (2013). doi:10.1002/jqs.2647

51. Giaccio, B. et al. Tephra layers from Holocene lake sediments of the Sulmona Basin, Central Italy: implications for volcanic activity in Peninsular Italy and tephrostratigraphy 
in the Central Mediterranean area. Quat. Sci. Rev. 28, 2710-2733 (2009). doi:10.1016/j.quascirev.2009.06.009

751

752

753

754

755

756

757

758

759

760

761

762

763

764

765

766

767

768

769

770

52. Petrosino, P. et al. The Montalbano Jonico marine succession: An archive for distal tephra layers at the Early-Middle Pleistocene boundary in southern Italy. Quat. Internat. 383, 89-103 (2015). doi:10.1016/j.quaint.2014.10.049

53. Ciaranfi, N. et al. Integrated stratigraphy and astronomical tuning of Lower-Middle Pleistocene Montalbano Jonico section (Southern Italy). Quat. Internat. 219, 109-120 (2010). doi:10.1016/j.quaint.2009.10.027

54. Massari, F. et al. Interplay between tectonics and glacio-eustasy: Pleistocene succession of the Crotone basin, Calabria (southern Italy). Geol. Soc. Am. Bull. 114, 1183-1209 (2002). doi:10.1130/0016-7606(2002)114<1183:IBTAGE >2.0.CO;2

55. Capraro, L. et al. Climatic patterns revealed by pollen and oxygen isotope records across the Matuyama-Brunhes Boundary in the central Mediterranean (southern Italy). Geol. Soc., London, Spec. Publ. 247, 159-182 (2005). doi:10.1144/GSL.SP.2005.247.01.09

56. Capraro, L. et al. Chronology of the Lower-Middle Pleistocene succession of the southwestern part of the Crotone Basin (Calabria, Southern Italy). Quat. Sci. Rev. 30, 1185-1200 (2011). doi:10.1016/j.quascirev.2011.02.008

57. Giaccio, B. et al. Duration and dynamics of the best orbital analogue to the present interglacial. Geology 43, 603-606 (2015). doi:10.1130/G36677.1

58. Sagnotti, L. et al. Extremely rapid directional change during Matuyama-Brunhes geomagnetic polarity reversal. Geophys. J. Internat. 199, 1110-1124 (2014). doi:10.1093/gji/ggu287 
59. Sagnotti, L. et al. How fast was the Matuyama-Brunhes geomagnetic reversal? A new subcentennial record from the Sulmona Basin, central Italy. Geophys. J. Internat. 204, 798-812 (2016). doi:10.1093/gji/ggv486

60. Simon, Q. et al. Authigenic ${ }^{10} \mathrm{Be} /{ }^{9} \mathrm{Be}$ ratio signature of the Matuyama-Brunhes boundary in the Montalbano Jonico marine succession. Earth Planet. Sci. Lett. 460, 255-267 (2017). doi:10.1016/j.eps1.2016.11.052

61. Rio, D. et al. Reading Pleistocene eustasy in a tectonically active siliciclastic shelf setting (Crotone peninsula, southern Italy). Geology 24, 743-746 (1996). doi:10.1130/00917613(1996)024<0743:RPEIAT>2.3.CO;2

62. Macri, P., Capraro, L., Ferretti, P. \& Scarponi, D. A high-resolution record of the Matuyama-Brunhes transition from the Mediterranean region: The Valle di Manche section (Calabria, Southern Italy). Phys. Earth Planet. Inter. 278, 1-15 (2018). doi:10.1016/j.pepi.2018.02.005

63. Giaccio, B., Hajdas, I., Isaia, R., Deino, A. \& Nomade, S. High-precision ${ }^{14} \mathrm{C}$ and ${ }^{40} \mathrm{Ar} /{ }^{39} \mathrm{Ar}$ dating of the Campanian Ignimbrite (Y-5) reconciles the time-scales of climatic-cultural processes at 40 ka. Sci. Rep. 7, 45940 (2017). doi:10.1038/srep45940

64. Regattieri, E., et al. A last Interglacial record of environmental changes from the Sulmona Basin (central Italy). Palaeogeogr. Palaeoclimatol. Palaeoecol. 472, 51-66 (2017). doi:10.1016/j.palaeo.2017.02.013

65. Giaccio, B. et al. First integrated tephrochronological record for the last $\sim 190 \mathrm{kyr}$ from the Fucino Quaternary lacustrine succession, central Italy. Quat. Sci. Rev. 158, 211-234 (2017). doi:10.1016/j.quascirev.2017.01.004

66. Laurenzi, M. A. \& Villa, I. ${ }^{40} \mathrm{Ar} /{ }^{39} \mathrm{Ar}$ chronostratigraphy of Vico ignimbrites. Period. Mineral. 56, 285-293 (1987) 
67. Karner, D. B., Marra, F. \& Renne, P. R. The history of the Monti Sabatini and Alban Hills volcanoes: groundwork for assessing volcanic-tectonic hazards for Rome. $J$. Volcanol. Geotherm. Res. 107, 185-219 (2001). doi: 10.1016/S0377-0273(00)00258-4

68. Mercer, C. M. \& Hodges, K.V. ArAR - A software tool to promote the robust comparison of $\mathrm{K}-\mathrm{Ar}$ and ${ }^{40} \mathrm{Ar} /{ }^{39} \mathrm{Ar}$ dates published using different decay, isotopic, and monitor-age parameters. Chem. Geol. 440, 148-163 (2016). doi:10.1016/j.chemgeo.2016.06.020

69. Blaauw, M. \& Christen, J. A. Flexible paleoclimate age-depth models using an autoregressive gamma process. Bayes. Analys. 6, 457-474 (2011). doi:10.1214/ba/1339616472

70. Grant, K. M. et al. Rapid coupling between ice volume and polar temperature over the past 150,000 years. Nature 491, 744-747 (2012). doi:10.1038/nature11593

71. Goosse, H. et al. Description of the Earth system model of intermediate complexity LOVECLIM version 1.2. Geosci. Model Dev. 3, 603-633 (2010). doi:10.5194/gmd-3$603-2010$

72. Opsteegh, J. D., Haarsma, R. J., Selten, F. M. \& Kattenberg A. ECBILT: a dynamic alternative to mixed boundary conditions in ocean models. Tellus, Ser. A, Dyn. Meterol. Oceanogr. 50, 348-367 (1998). doi:10.3402/tellusa.v50i3.14524

73. Goosse, H. \& Fichefet, T. Importance of ice-ocean interactions for the global ocean circulation: A model study. J. Geophys. Res. 104, 23337-23355 (1999). doi:10.1029/1999JC900215

74. Brovkin, V., Ganopolski, A. \& Svirezhev, Y. A continuous climate-vegetation classification for use in climate-biosphere studies. Ecol. Modell. 101, 251-261 (1997). doi:10.1016/S0304-3800(97)00049-5 
75. Timmermann, A. et al. obliquity and $\mathrm{CO}_{2}$ effects on Southern Hemisphere climate during the past 408 ka. J. Clim. 27, 1863-1875 (2014). doi:10.1175/JCLI-D-13-00311.1

76. Berger, A. Long-term variations of daily insolation and Quaternary climate change. $J$. Atmos. Sci. 35, 2362-2367 (1978). doi:10.1175/15200469(1978)035<2362:LTVODI >2.0.CO;2

77. Lüthi, D. et al. High-resolution carbon dioxide concentration record 650,000-800,000 years before present. Nature 453, 379-382 (2008). doi:10.1038/nature06949

78. EPICA community members. Eight glacial cycles from an Antarctic ice core. Nature 429, 623-628 (2004). doi:10.1038/nature02599

79. Ganopolski, A. \& Calov, R. The role of orbital forcing, carbon dioxide and regolith in 100 kyr glacial cycles. Clim. Past, 7, 1415-1425 (2011). doi: 10.5194/cp-7-1415-2011

80. Hammer, O. PAleontological Statistics (PAST) Version 3.21 reference manual, Natural History Museum, University of Oslo (2018). https://folk.uio.no/ohammer/past/

81. Torrence, C. \& Compo, G. P. A practical guide to wavelet analysis. Bull. Am. Meteorol. Soc. 79, 61-78. (1998). doi:10.1175/1520-0477(1998)079<0061:APGTWA>2.0.CO;2

82. Lindhorst, K. et al. Sedimentary and tectonic evolution of Lake Ohrid (Macedonia/Albania). Basin Res. 27, 84-101 (2015). doi:10.1111/bre.12063

83. Melard, G. Algorithm AS 197: A fast algorithm for the exact likelihood of autoregressive-moving average models. Appl. Stat. 33,104-114 (1984). doi:10.2307/2347672

84. Bar-Matthews, M., Ayalon, A., Gilmour, M., Matthews, A. \& Hawkesworth, C. J. Sealand oxygen isotopic relationships from planktonic foraminifera and speleothems in the Eastern Mediterranean region and their implication for paleorainfall during interglacial 
intervals. Geochim. Cosmochim. Acta 67, 3181-3199 (2003). doi: 10.1016/S00167037(02)01031-1

844

845

846

847

85. Zanchetta, G. et al. Aligning and synchronization of MIS5 proxy records from Lake Ohrid (FYROM) with independently dated Mediterranean archives: implications for DEEP core chronology. Biogeosciences, 13, 2757-2768 (2016). doi:10.5194/bg-13-27572016

86. Le Bas, M. J. Le Maitre, R. W. Streckeisen, A. \& Zanettin, B. A Chemical Classification of Volcanic Rocks Based on the Total Alkali-Silica Diagram. J. Petrol. 27, 745-750, (1986). doi:10.1093/petrology/27.3.745

87. Wagner, B. et al. The last 40 ka tephrostratigraphic record of Lake Ohrid, Albania and Macedonia: a very distal archive for ash dispersal from Italian volcanoes. J. Volcanol. Geotherm. Res. 177, 71-80 (2008). doi:10.1016/j.jvolgeores.2007.08.018.

88. Zanchetta, G. et al. Tephrostratigraphy, chronology and climatic events of the Mediterranean basin during the Holocene: An overview. Holocene 21, 33-52 (2011). doi:10.1177/0959683610377531

89. Siani, G., Sulpizio, R., Paterne, M. \& Sbrana, A. Tephrostratigraphy study for the last 18,000 C-14 years in a deep-sea sediment sequence for the South Adriatic. Quat. Sci. Rev. 23, 2485-2500 (2004). doi:10.1016/j.quascirev.2004.06.004.

90. Albert, P. G. et al. Revisiting the Y-3 tephrostratigraphic marker: a new diagnostic glass geochemistry, age estimate, and details on its climatostratigraphical context, Quat. Sci. Rev. 118, 105-121 (2015). doi:10.1016/j.quascirev.2014.04.002

91. Satow, C. et al. A new contribution to the Late Quaternary tephrostratigraphy of the Mediterranean: Aegean Sea core LC21, Quat. Sci. Rev. 117, 96-112 (2015). doi:10.1016/j.quascirev.2015.04.005 
92. Giaccio, B. et al. Isotopic (Sr-Nd) and major element fingerprinting of distal tephras: an application to the Middle-Late Pleistocene markers from the Colli Albani volcano, central Italy. Quat. Sci. Rev. 67, 190-206 (2013). doi: 10.1016/j.quascirev.2013.01.028

93. Petrosino, P., Jicha, B. R., Mazzeo, F. C. \& Russo Ermolli, E. A high resolution tephrochronological record of MIS 14-12 in the Southern Apennines (Acerno Basin, Italy). J. Volcanol. Geotherm. Res. 274, 34-50 (2014). doi:10.1016/j.jvolgeores.2014.01.014

94. Marra, F., Karner, D. B., Freda, C., Gaeta, M. \& Renne, P. Large mafic eruptions at Alban Hills Volcanic District (Central Italy): Chronostratigraphy, petrography and eruptive behavior. J. Volcanol. Geotherm. Res. 179, 217-232 (2009). doi:10.1016/j.jvolgeores.2008.11.009

\section{Data Availability}

Data are available in the main text, in the supplementary materials and in the Pangaea database at https://doi.pangaea.de/10.1594/PANGAEA.896848. Data used for LOVECLIM are available at https://climatedata.ibs.re.kr/grav/data/loveclim-784k.

\section{Code Availability}

Model data produced by the LOVECLIM simulations are available through the data centre of the IBS Center for Climate Physics: https:/climatedata.ibs.re.kr/grav/data/loveclim-784k. Additional data are available upon request made to Tobias Friedrich (tobiasf@hawaii.edu).

\section{Extended Data Legends}


Extended Data Figure 1 | Map of Lake Ohrid and its surrounding area. Geology,

891

892

893

894

895

896

897

898

899

900

901

902

903

904

905

906

907

908

909

910

911

912

913

914

915 topography, and bathymetry compiled from ${ }^{19,82}$ and geological maps of Albania and North Macedonia. The lake is located at an altitude of $693 \mathrm{~m}$ a.s.l. and has a maximum water depth of $293 \mathrm{~m}$. The water depth at the DEEP drill site is $240 \mathrm{~m}$.

\section{Extended Data Figure 2 | Correlation of tephra layers at the DEEP site with tephra} layers found in mid-distal records. $\mathrm{Bi}$-oxide plots of (a) $\mathrm{CaO}$ vs. $\mathrm{FeO}_{\text {total, }}$ (b) $\mathrm{CaO}$ vs. $\mathrm{Al}_{2} \mathrm{O}_{3}$, (c) $\mathrm{CaO}$ vs. $\mathrm{TiO}_{2}$, (d) $\mathrm{Na}_{2} \mathrm{O}$ vs. $\mathrm{K}_{2} \mathrm{O}$, and (e) total alkali vs. silica (TAS) diagram ${ }^{86}$ show the correlation of OH-DP-2669 with the tephra layers SC1-35.30/SUL2-1/V5 and the differences to the Parmenide ash. Bi-oxide plots of (f) $\mathrm{CaO}$ vs. $\mathrm{FeO}_{\text {total }}$, (g) $\mathrm{CaO}$ vs. $\mathrm{Al}_{2} \mathrm{O}_{3}$, (h) $\mathrm{CaO}$ vs. $\mathrm{TiO}_{2}$, (i) $\mathrm{Na}_{2} \mathrm{O}$ vs. $\mathrm{K}_{2} \mathrm{O}$, and (k) TAS diagram show the correlation of OH-DP-2898 with tephra SUL2-22 and the differences to SUL2-23, -27, -31, V4, V3, and the Pitagora ash. Error bars of the Parmenide Ash refer to ${ }^{54}$.Tephra ages, geochemical data, tephrostratigraphic discussion and references are provided in Extended Data Tables 1 and 2 and in Methods.

\section{Extended Data Figure 3 | Lake Ohrid LOVECLIM simulation data and sedimentary} paleoclimate and paleoenvironment proxies. (a) Simulated surface-air temperature (SAT) for the Lake Ohrid grid cell from the LOVECLIM simulation; (b) simulated precipitation amount for the Lake Ohrid grid cell from the LOVECLIM simulation; (c) Lake Ohrid total organic carbon (TOC) concentrations; (d) Lake Ohrid $\delta^{13} \mathrm{C}$ endogenic calcite in \%o relative to VPDB; (e) Lake Ohrid $\delta^{18} \mathrm{O}$ endogenic calcite in \%o relative to VPDB; (f) Lake Ohrid relative sedimentary quartz content; (g) Lake Ohrid K intensities in kilo counts and displayed using a 11 pt running mean; (h) Lake Ohrid ratio of $\mathrm{Ca} / \mathrm{K}$ intensities displayed using a 11 pt running mean; (i) Lake Ohrid Ca intensities in kilo counts and displayed using a 11 pt running mean; (k) Lake Ohrid total inorganic carbon (TIC) concentrations; (l) Lake Ohrid deciduous oaks pollen percentages; (m) Lake Ohrid arboreal pollen excluding Pinus pollen (AP-P) 
916 percentages; red and white diamonds indicate the position of radiometrically dated tephra

917 layers, blue and white diamonds the position of reversals of Earth's magnetic field in the Lake

918 Ohrid sediment record. (b), (d), (e), (K), (l) and (m) are from Fig. 2.

919

920 Extended Data Figure 4 | Data analysis. Continuous wavelet transform results for

921 percentages of total inorganic carbon (TIC; a) and deciduous oak pollen (b) time series from

922 Ohrid DEEP where colour represents the signal amplitude at a given time and spectral period

923 (yellow highest, red lowest power). Black contour is the 5\% significance level (chi-squared

924 test according to ${ }^{81}$ ) against a red-noise background spectrum with autocorrelation coefficient

925 of 0.95 , estimated through an autoregressive-moving-average (ARMA) model implemented

926 in PAST $\left({ }^{80}\right.$ based on $\left.{ }^{83}\right)$. Thick grey line indicates the "cone of influence" outside of which

927 boundary effects can influence the results. Least squares regression (red line) between band

928 pass-filtered 18-25 ky component of (c) \% TIC and (d) the \% deciduous oak against

929 precession at 1 ky resolution. Blue lines indicate $95 \%$ bootstrapped $(n=1999)$ confidence

930 intervals. Results show significant negative relationships for both proxies, with a stronger

931 response (steeper slope) of the deciduous oaks. Partial least squares regression (PLSR) using

932 TIC and deciduous oaks as predictive variables and LOVECLIM (e) temperature and (f)

933 precipitation output data as observations. PLSR was performed using SIMCA 14 (Sartorius

934 Stedim Biotech). All datasets were filtered using a frequency centred at 0.05 and a bandwidth

935 of 0.02 prior to multivariate statistical analysis to accommodate for slight offsets in age

936 differences between proxy and simulation data. Results show highly significant positive

937 correlations of simulated temperatures (e) and of simulated precipitation (f) data to proxy

938 data, with a higher sensitivity of TIC and deciduous oaks towards changes in precipitation

939 compared to temperature.

940 
records during MIS 5. (a) Ages of sapropels and humid phases in the Eastern Mediterranean

944 precipitation amount for the Lake Ohrid grid cell from the LOVECLIM simulation; (c) Lake

945 Ohrid deciduous oaks pollen percentage; (d) Lake Ohrid total inorganic carbon (TIC)

946 concentrations; (e) Chinese Speleostack $\delta^{18} \mathrm{O}^{25}$ in \%o relative to VPDB; red and white

947 diamonds indicate the position of radiometrically dated tephra layers in the Lake Ohrid

948 record. The chronology of the MIS 5 interval in the Lake Ohrid DEEP site record is based on $949 \quad 85$.

Extended Data Figure 6 | Simulated Lake Ohrid precipitation for full-forcing run and

952 sensitivity simulations. (a) Lake Ohrid precipitation $\left(\mathrm{cm} \mathrm{yr}^{-1}\right)$ for full-forcing simulation

953 (black) and a simulation using only orbital forcing under a warm background climate (red).

954 (b) Black line as in (a) and a simulation using only orbital forcing under a cold background

955 climate (blue). (c) Black line as in (a) and a simulation using full-forcing except for a constant

956 preindustrial NH ice sheet. (d) Black line as in (a) and a simulation using full-forcing except

957 for constant preindustrial GHG concentrations. Please note that the sensitivity simulations

958 only cover the last 408 kyr. Please see Methods for details on the sensitivity simulations.

\section{Extended Data Figure 7 | NOAA reanalysis data for the Mediterranean region. (a)}

961 Reconstructed precipitation $\left(\mathrm{cm} \mathrm{yr}^{-1}\right)$ for the Lake Ohrid reanalysis grid cell. Data based on

962 monthly means. Dashed line indicates two standard deviations above the mean. (b) Composite

963 anomalies of $850 \mathrm{hPa}$ geopotential height $(\mathrm{m})$ associated with Lake Ohrid precipitation

964 maxima shown in (a) and referring to the months shown in (c). (c) Monthly distribution of

965 precipitation maxima shown in (a). 
967 Extended Data Figure 8 |. Mean seasonal cycle of Lake Ohrid precipitation - model

968 simulation and NOAA reanalysis data. (a) Mean seasonal cycle of simulated Lake Ohrid

969 precipitation $\left(\mathrm{cm} \mathrm{yr}^{-1}\right)$ for all model years (green) and model years with annual-mean

970 precipitation exceeding two standard deviations (magenta). Please see also Fig. 3a. (b) Mean

971 seasonal cycle of Lake Ohrid precipitation $\left(\mathrm{cm} \mathrm{yr}^{-1}\right)$ derived from NOAA reanalysis data

972 (blue) and simulated for the 1-0 kyr period (red). The annual means were removed for better

973 comparison and are provided in the panel.

974

975 Extended Data Table 1 | Selected tephra layers from Lake Ohrid and their correlation

976 with tephra layers of other records. ${ }^{40} \mathrm{Ar} /{ }^{39} \mathrm{Ar}$ ages from literature were recalculated using a 977 decay constant ${ }^{73}$ and Alder Creek sanidine (ACs-2) at $1.1891 \mathrm{Ma}^{74}$ or Fish Canyon sanidine 978 (FCs) at $28.294 \mathrm{Ma}^{73}$. Tephra ages in bold are used for age-depth modelling in Fig. 1. Age 979 uncertainties are provided according to the original reference (Reference age).

980

981 Extended Data Table 2 | Average compositions of OH-DP-2669 and OH-DP-2898 and 982 potential equivalent correlations. Data of SUL2-1, SUL2-22, SUL2-23, SUL2-27 from ${ }^{51}$;

983 SC1-35.50 from ${ }^{50} ; \mathrm{V} 5, \mathrm{~V} 4, \mathrm{~V} 3$, Pitagora ash from ${ }^{52}$ and the Parmenide ash from ${ }^{54} . \overline{\mathrm{x}}=$ 984 mean; $\mathrm{S}=$ standard deviation; $\mathrm{n}=$ number of analysis. 
Fig. 1

987

(b)

TOC Insolation

(W m ${ }^{-2}$ )

(a)
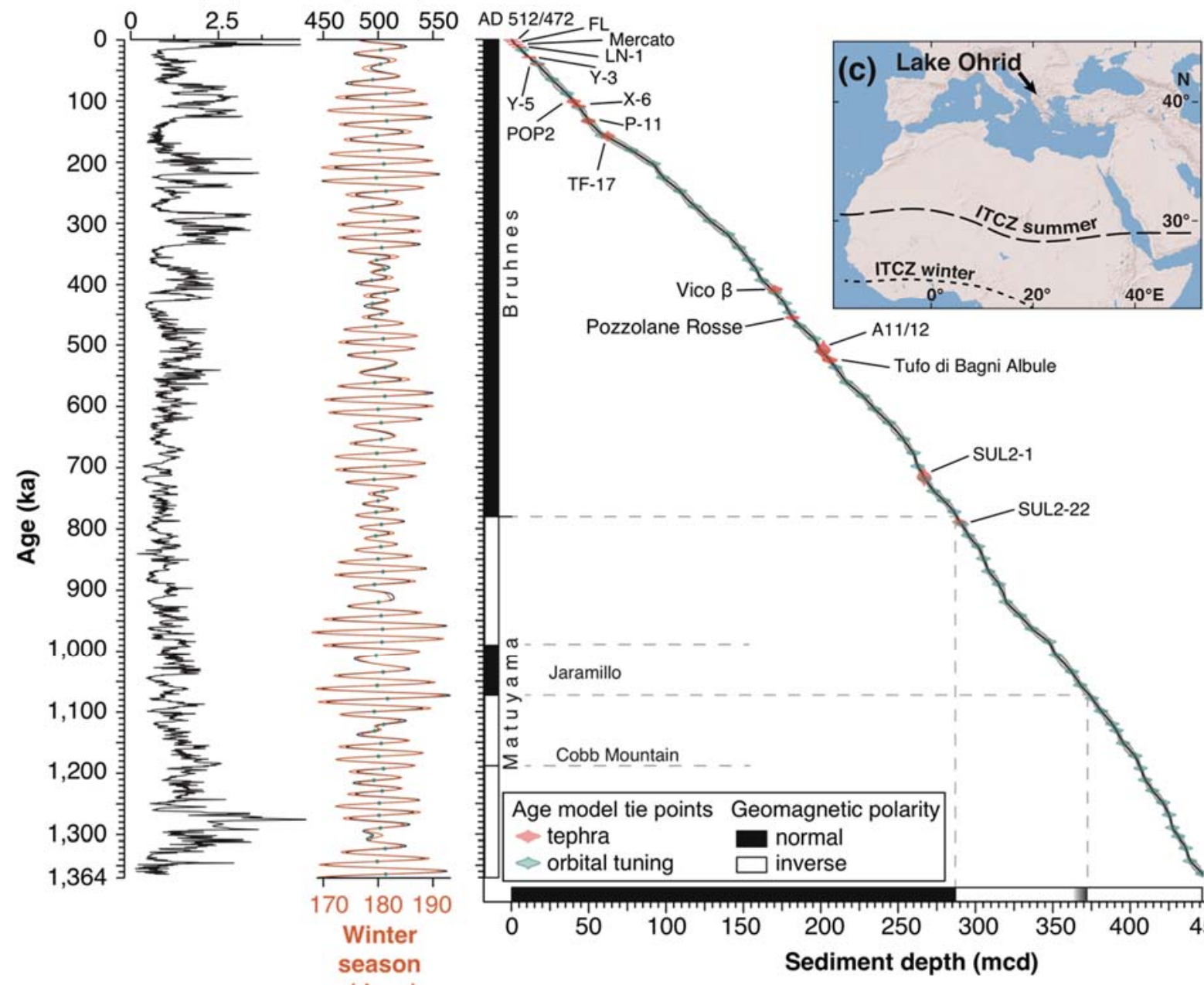

(days) 


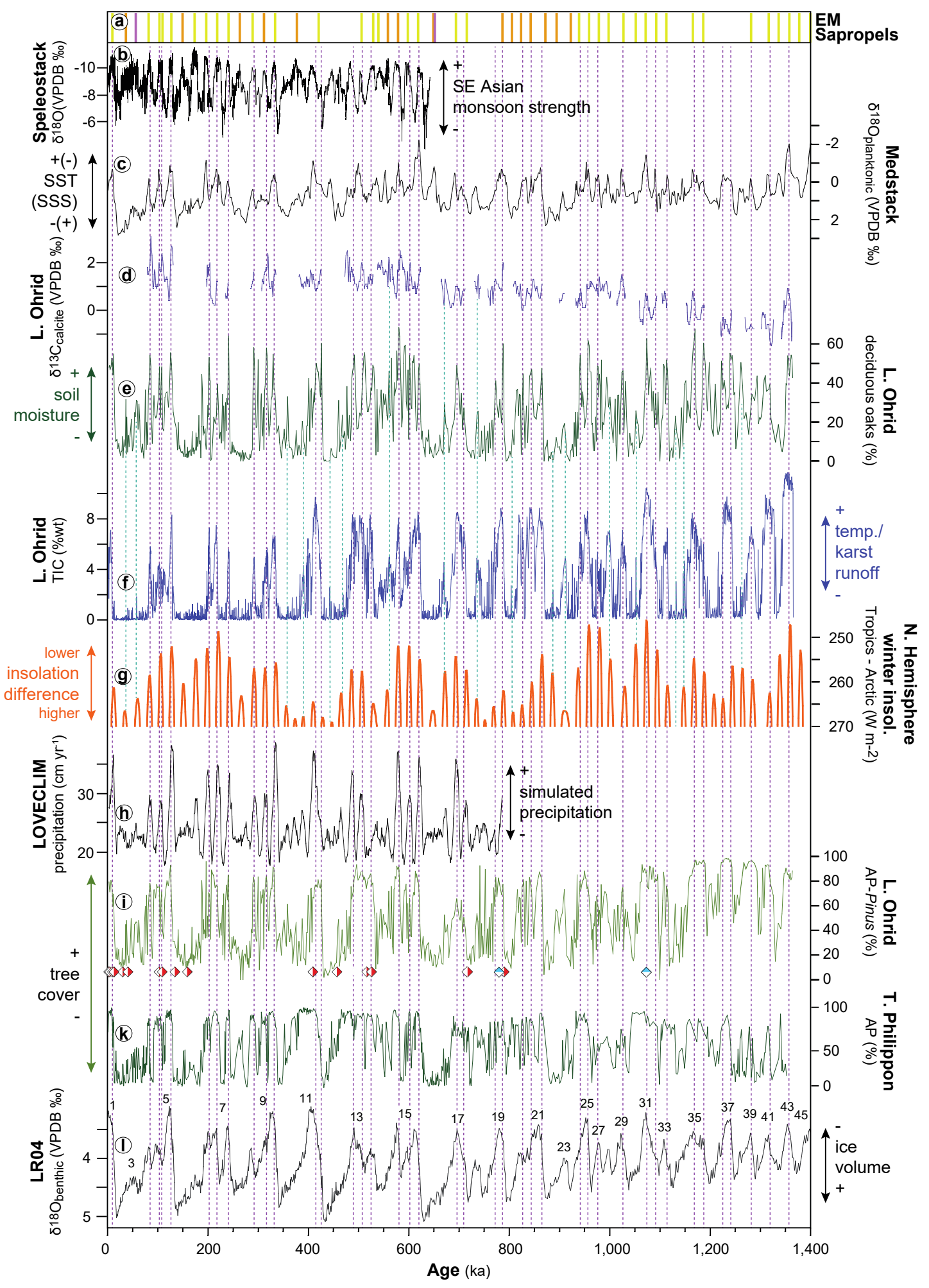


Fig. 3

996

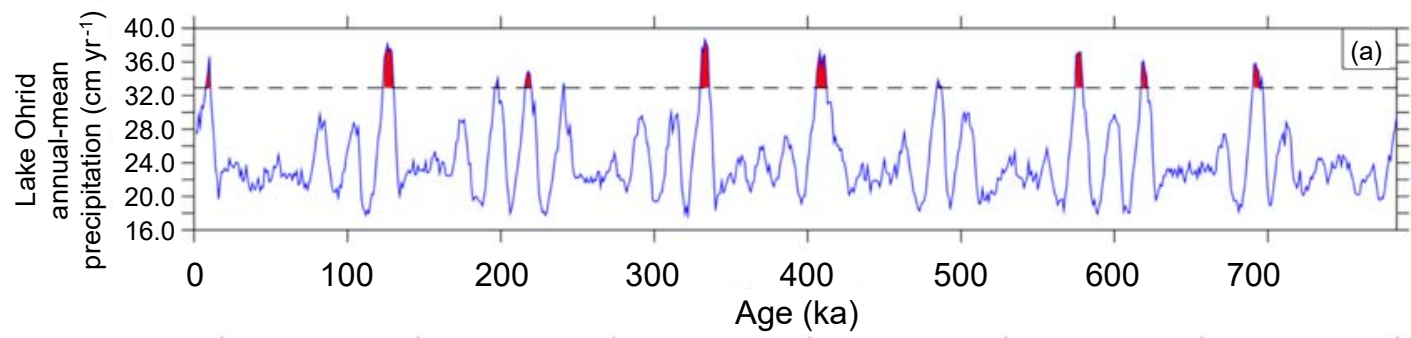

997

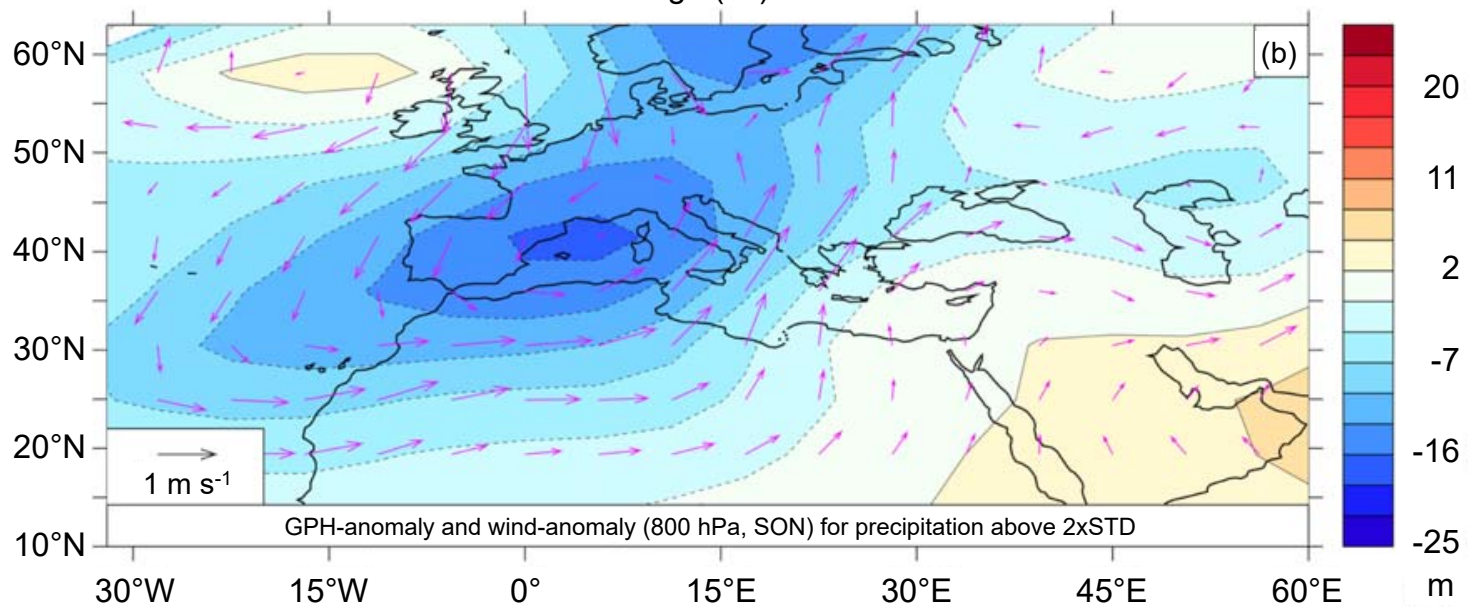

